\title{
Transnationalism and the Creative Imagination: A Comparative Study of William Shakespeare's The Tempest and Esiaba Irobi's Sycorax
}

\author{
Omeh Obasi Ngwoke* Laurel Chikwado Madumere \\ Department of English Studies, University of Port Harcourt, PO box 5323, Port Harcourt, Nigeria
}

\begin{abstract}
Since the beginning of the twenty-first century, African literature has witnessed a significant shift from its attention from peculiar national cultures, discrete experiences and traditional practices to more global paradigms. The global or transnational approach to literary studies weakens the writers' roles as committed vanguards of their indigenous cultures and reconfigures their works to accommodate exponential global issues and postmodern characters. Due to the newness of this transnational turn in African literary enterprise, scholars still grapple with its tenets and application. Therefore, the aim of this paper is to engage archetypal, borderless or transnational plays in the demonstration of the methods some postcolonial writers have applied in the demolition of geographical and historical boundaries especially via appropriations. Its significance lies in its ability to open up new perspectives to the study of Shakespeare's The Tempest and Irobi's Sycorax which will aid the understanding of the features of globalization in African literature. The paper is qualitative in approach and is based on Homi Bhabha's strand of the postcolonial theory. Seen in the light of the above, the paper concludes that African literature is advancing speedily, like its European counterpart, in the exploration of the peculiarities of (a) global capital.
\end{abstract}

Keywords: Transnationalism, African literature, global character, postcolonial theory, The Tempest, Syorax,

DOI: $10.7176 /$ JLLL/65-05

Publication date: February $29^{\text {th }} 2020$

\section{Introduction}

Transnationalism implies the idea of extending or operating across national boundaries. It finds expression in literature when writers engage their works with issues of international significance. Transnational literature boasts subjects that transcend the burning issues within the nationalities of their authors and rather focus on issues of global or, at least, international importance; or concerns that connect nationalities. Esiaba Irobi's Sycorax is such a work. The allure of Sycorax rests on its engagement not only with issues that go beyond his national boundaries/concerns, but also those that transcend the boundaries of age and space as the $21^{\text {st }}$ century Nigerian-authored play deals with issues associated with the Renaissance and Elizabethan England and of course with William Shakespeare and his last comic drama, The Tempest.

Considered the greatest dramatist of all times, Shakespeare, before his death, produced literary works, especially plays that have remained sources of inspiration to writers down the ages either in terms of their archetypal signification or in their general aesthetic import manifesting chiefly in the masterly manipulation of poetic language and in the adroit handling of the verse structure. Just like many other writers of disparate origin, Irobi is believed to have in Sycorax, his last play before his death, relied on the man whom J. P. Clark Bekederemo (1970) refers to as "...master in and out of the trade" (Blurb, The Example of Shakespeare) for some kind of inspiration and obviously in the bid to lunch himself and his dramatic output on the global stage.

This new leap into the international arena, according to Irobi (2013) “...marks a new approach to my playwriting and theater-making process" (p. 5). Earlier in the same note, he had described Sycorax as an "adaptation of William Shakespeare's The Tempest" (Irobi, 2013, p. 5). And later on, the foremost Irobi scholar, Isidore Diala (2014) corroborates the view that Sycorax is an adaptation of The Tempest (p. 200). In this regard, Sycorax ranks among such other Nigerian plays describable as the re-writings of European archetypal national plays as John Pepper Clark-Bekederemo's Song of a Goat, Wole Soyinka's Bacchae of Euripides: A Communion Rite, Ola Rotimi's The Gods Are Not to Blame, and Femi Osofisan's Togoni, an African Antigone and Women of Owu.

While the above declarations of Irobi and Diala remain relevant to the study of Sycorax, and by extension, The Tempest, it is important in this study to attempt an interrogation of the said declaration. Here then lies the significance of this study which seeks to closely examine craft and content in both plays with a view to determining what Irobi actually does with The Tempest to evolve Sycorax. To actualize this, the study calls to its aid Homi Bhabha's strand of the Post-colonial theory based on whose tenets it attempts proffering answers to such fundamental questions as: What is adaptation? What are the features or rules of adaptation? Does Sycorax depict adherence to these rules? Is there actually a link between The Tempest and Sycorax whether in the form of adaptation or otherwise? Could Irobi's declaration concerning Sycorax being an adaptation of The Tempest have 
been a misjudgement of what he actually did in the play? If, in the final analysis, what Irobi has done in Sycorax does not constitute an adaptation, what then does it amount to? How is Sycorax a transnational literature?

\section{The Evolution of Transnationalism in African Literature}

The written African literature, unarguably, came to limelight in the mid twentieth century with works done by such West African writers as Chinua Achebe, Wole Soyinka, Ayi Kwei Ahmah and Kofi Awoonor; Southern African writers like Mazisi Kunene, Dennis Brutus, Nadine Gordimer and Andre Brink; and a few East African writers like Ngugi wa Thiong'o and Okot p'Btek, etc. That flowering of literary products was motivated by events that characterized the period, events that occurred not in the academe, but in the larger political sphere of the continent. The mid twentieth century (1950-1960) alone witnessed the independence of twenty-three African countries from imperialism; starting with Libya on the $24^{\text {th }}$ of December, 1951 and ending with Mauritania on the $28^{\text {th }}$ of November 1960. Almost all African countries had their independence in the twentieth century except Liberia on July $26^{\text {th }}, 1847$.

Writers, especially nationalist writers employed the ideologies of their discrete national movements and tended to canonize those ideologies and make them predominant literary motifs of the century. A typical example is the triumph of the negritude ideologies of Senghor in Francophone literary output in the twentieth century. In the literature of the Anglophone countries of West Africa, the nationalist ideals come in forms of cultural affirmations in the novels of Achebe and Ahmah, the plays of Soyinka and Clark and others. In East African literature of the century, nationalism reverberate in the poems of Okot p'Btek, the novels of Ngugi wa Thiong'o, etc., while in Southern African literature of the century, nationalism takes the form of the themes of agitation for the emancipation of the Blackman from the hegemonies of the apartheid regime in the novels of Brink, the poems of Dennis Brutus, the plays of Lewis Nkosi and others.

All through the twentieth century, the predominant literary motif in Africa was focused on the subdued or muted cultural beliefs that want to be heard; certain distinct national experiences; and/or pan-African thesis. Speaking of the African literature at this time, Achebe (2012) avers as follows:

African art as we understand it has not been distilled or purified to the point where it has lost all traces of real life, lost the vitality of the street, like art from some advanced societies and academic art tend to be. In Africa the tendency is to keep art involved with the people. It is clearly emphasized among my own Igbo people that art must never be allowed to escape into the rarefied atmosphere but must remain active in the lives of the members of the society. (p. 56)

What Achebe points at is the need for the representation of life and the society of Africans in African literature. For him, it is important, at that stage in the development of African literature, to fashion literature to tow the lines of its oral predecessor in its thematic preoccupation and ideology of bringing the aesthetic values of indigenous cultures to global recognition. Achebe may have alluded to his Igbo tradition, but in general, his opinion is that African literature in the twentieth century tilts towards the indigenous cultures of the nations of the authors or towards events that culminate to nation building.

By the year 2000, virtually all African countries have got their independence. Many of the independent countries had fought civil wars like Nigeria, and many others were still fighting or had divided like Sudan. Some countries like Ghana had witnessed a form of revolution, while others had passed through economic and political policies that had transformed the attitude and mind-set of the citizens to xenophobic inclinations such as we find in South Africa, such that by the twenty-first century the bond of nationalism or pan-Africanism had begun to wane and shatter. Consequently, this break in national tendencies and attention found its way into the literature of the twenty-first century.

One of the obvious consequences of the threats to nationalism is that most of the literary traditions which were overtly nationalist in nature began to lose interest in nationalisms and rather expanded beyond the boundaries of their immediate milieus, beyond the borders of the continent of Africa to seek other frontiers and inclinations for fulfilment. In addition to those threats by xenophobia, terrorism, civil wars, ethnic cleansings, secessionisms and revolutions are the twenty-first century subscriptions to theories of post-colonialism, ecocriticism, studies in the LGBT (Lesbian, Gay, Bi-sexual, and Transgender studies), and finally - transnationalism.

Paul Jay (2010) has argued that "during the same period postcolonial studies emerged to challenge the primacy of discrete national literatures and what seemed like their insular concerns, providing a framework for studying literature and culture in a transnational context that moved beyond and explicitly questioned older Eurocentric models of 'comparative' analysis" (pp. 1-2). Postcolonial literatures had existed for decades before the twenty-first century. Alan Paton's novel Cry, Beloved Country (1948) in its South African context is considered to be a postcolonial novel. Thus, what Paul Jay refers to is the exponential increase in the production of literary texts that follow the logics of postcolonial theory to appropriate items from postcolonial countries which are beyond the continent of Africa: India, Pakistan, etc. This latter postcolonial tradition questions and weakens the twentieth century attention on discrete cultures by introducing other similar cultures into the study 
of African literature.

Our focus in this study is on the transnational turn in the study of African literature and its roots in postcolonial discourses. What interests us more is an understanding of the ways those threats enumerated above have weakened nationalisms and have given rise to the transnational approach to the study of African literature. Transnationalism in African literature just as elsewhere, Jay (2010) would want us to know, “...has productively complicated the nationalist paradigm long dominant in these fields, transformed the nature of the locations we study, and focused our attention on forms of cultural production that take place in the liminal spaces between real and imagined borders" (p. 1). What he implies is that transnationalism in the twenty-first century has charted a new course to approach what we call African literature, it has redefined the places we study, the types of literatures and cultures we analyze (e.g. English cultures) and has added new motifs that are hitherto unconsidered to African literary enterprises.

Transnationalism, as we conceive it here, implies that one can look beyond the apartheid motifs of Paton, the Igbo and Yoruba cosmologies of Achebe and Soyinka, the Gikuyu conception of land in Ngugi, or the Islamic agenda of Cheikh Hamidou Kane of the twentieth century to the transcendental borders of the magical, the world of the LGBT, or to Euro-American cultures to appropriate items or literary modes to enhance the body of written African fiction.

\section{Theoretical Framework}

Due, mainly, to its borderless approach, this paper adopts a postcolonial theoretical framework which is rooted in Homi Bhabha's concept of hybridity. In his The Location of Culture, Bhabha (1994) contends that colonialism, and perhaps any form of contact in that nature, brought about the transportation of a supposed homogenous culture into another culture. The resultant clash produced what he calls the "The Third Space of enunciation" (p. 37). The space exists in the liminal margins between the cultures that are operating parallel to each other within the region(s). In a typical postcolonial country, what Bhabha suggests is that there is a new hybrid culture that exists, which is an aftermath of the diffusion of European and indigenous cultural values. The precipitated culture is a global or transnational culture which indicates that the symbols of one culture (or more) can be appropriated, subverted and integrated to form newer versions.

Thus, the Third "split-space of enunciation may open the way to conceptualizing an international culture, based not on the exoticism of multiculturalism or the diversity of cultures, but on the inscription and articulation of culture's hybridity" (Bhabha, 1994, p. 38). What he implies is that what eventually emerges as the third culture in the post-colony is a syncretic and synergetic international culture. In the field of literature, we would therefore say that colonial contact introduced Eurocentric, homogeneous or discrete literatures into the colony. Thus, in the post-colony, the product of such contact is the hybrid or transnational literatures that evolved and are still evolving.

The signs of the hybrid literary culture are greatly and sharply presented in the form of the Creole and pidgin languages that pervade such literary texts. The signs are also made visible via the creation of global characters that live in between the spaces of the two (or more) contending cultures. Hence, that colonial contact that birthed the global characters who inhabit "the in-between space" (Bhabha, 1994, p. 38) is a form of globalization. Jay (2010) has argued that one's definition of globalization is determined by one's acceptance of the different existing logics about the origin of globalization (p. 34).

On the one hand, some scholars consider globalization to be an aftermath of the recent sudden upsurge in technological innovations especially in the media that has brought the world to a global village. For the above scholars, globalization is new and contemporaneous. On the other hand, other scholars (to which Jay belongs), see it as being historically old and incorporates all global encounters like slave trades, colonialism, postcolonialism, etc.

For the latter scholars, Jay (2010) avers that they believe that “...it is important to think of globalization in longer historical terms, not so much because it is more accurate than seeing globalization as a contemporary phenomenon (both positions have their merits), but because it affords us a more nuanced historical perspective regarding the development of globalization in our own time" (p. 34). What he implies is that it is crucial to see globalization as being old so that it shall give us a more and wider coverage of all its manifestations in history. To see globalization as being historically old is to see all forms of global contacts - the discoveries of sea routes, the trade on the human species, colonial expansion, and missionary journeys - as global encounters. This view is helpful to us because it helps us to see Shakespeare's The Tempest not just as a national literature, but as one of the earliest forms of colonial contacts and of escapes from national barriers.

There are numerous definitions of globalization, but the one adopted for the purpose of this study is that put forward by Anthony Giddens. Giddens (1991) sees globalization as “...the intensification of social relations throughout the world, linking distant localities in such a way that local happenings are formed as a result of events that occur many miles away and vice versa" (p. 64). The above implies the spread of global cultural commodities in such a manner that the events of a particular location may be the aftermath of an acquired 
cultural item from another location. This is at the core of the present study: how particular plays spread abroad the cultures of their milieu in such a way as to determine and influence the production and reception of another hybrid play in a distant culture. How via the power of imagination, a playwright is able to appropriate and domesticate foreign perspectives as a result of the demolition of national walls that would have confined those literatures.

The demolition of the walls may be as a result of a shared colonial experience as in the case of postcolonial cultures, or shared cultural heritage as in the case of Diaspora discourses or similar ideologies like feminism. For pedagogy sake, our focus is on the process of sharing national literary commodities across continents and influences arising from adaptations and appropriations.

\section{The Tempest in Sycorax: A Case of Adaptation or Appropriation?}

In her effort to adumbrate the circumstances for adaptations, Linda Hutcheon makes two crucial propositions. Hutcheon (2006) maintains that adapters adapt works because of, firstly, the pleasures of the "piquancy of surprise" (p. 4) and secondly, which is more of an economic consideration, its "financial appeal" (p. 5). Financial profiting and pleasures are indeed not the reasons Irobi wrote Sycorax. Sycorax is (more like Achebe's Things Fall Apart is a response to Joyce Cary's and Joseph Conrad's and European misconceptions of Africa) a response to the Stratford Upon Avon and Euro-American audiences' conception of the other. Obviously, the difficulty the critics of Sycorax face while categorizing it as an adaptation is that foregrounded by Hutcheon (2006), "... the confusing simplicity of the word" adaptation, and the difference between "the process and the product" (p. 15) of adaptation.

As an adaptation, Sycorax is comparable to a translation or a paraphrase which it is not. Hutcheon (2006), privileging John Dryden, accepts that paraphrase is a "translation with latitude where the author is kept in view..., but his words not strictly followed as his sense and that too is admitted to be amplified" (p. 16). In Sycorax, Shakespeare is not kept in view, but he is a character in the dramaturgy. Thus, what is being paraphrased in Sycorax is not Shakespeare's The Tempest, but his private and public biographies. If we borrow Hutcheon (2006), we would say that Sycorax on the one hand, is a product of a paraphrase of "...an actual person's life into a re-imagined, fictional form" (p. 16). Thus, on the other hand, what is involved in the process of the creation of Sycorax is an "....act of appropriating or salvaging and this is always a double process of interpreting and then creating something new" (Hutcheon, 2006, p. 20). That new thing is Sycorax. It involves the art of stealing elements from the life and times of Shakespeare and subverting them to create an original or prototypical play. Sycorax is for us what Roland Barthes would call a text. For Barthes (1977), a text is made up of "stereophony of echoes, citations, references" (p. 160). Those citations and references account for intertextualities in literature. In Sycorax the intertextual references and citations are made to or derived from Shakespeare's life and The Tempest, but they operate at the levels of pastiche which should not be confused with adaptation.

Shakespeare's critics have argued that The Tempest is an adaptation of Virgil's Aeneid. Notable among those critics is Donna B. Hamilton who privileging "the theory and practice of rhetorical imitation" considers "The Tempest as a work that is a formal imitation of the first six books of the Aeneid, both in its larger patterns of theme and structure and in its smaller details of vocabulary and syntax" (Hamilton, 1990, p. 4). He adds that "...in Shakespeare's play [The Tempest], the Aeneid has been dismantled, reversed, and rewritten" (p. 4). He points out the salient scenes in Aeneid that form the background in The Tempest: the storm which rages at the sea, the shipwreck of the king and his crew and the love scenes. All those imitated elements constitute what Stephen Hinds has called "background noise" (p. 19).

To take us further, let us consider the position of Johannes Sturm. In his book entitled Nobilitas Liberata he chides his students to perfect the art of writing well (Sturm, trans. 1547). Well, for him means complete or total reworking of an imitated text. He asks them to look at Virgil and how perfectly he has imitated Theocritus and Homer. He draws the similarities that exist between Homer's lines and his creation of Achilles and Virgil's imitated lines and his creation of Aeneid (Sturm, trans. 1547, H3). If Virgil imitated Homer, and Shakespeare imitated Virgil and Irobi imitated Shakespeare, then it is logical to say that Irobi has appropriated a European continental literary culture, reworked it and situating it in the Caribbean.

Adaptation and appropriation are dichotomous in nature. Julie Sanders (2006) has argued that "adaptations and appropriations can possess starkly different, even opposing, claims and intentions" (p. 18). While an adaptation is usually aimed at making the original work easier to understand and updating it in line with contemporary standards, usually through a change of medium, for example, from text to film, an appropriation is aimed at insults and defiance for the other text. Appropriation is critical for the work it is appropriating. Thus, Sanders (2006) adds that "appropriation... adopts a posture of critique, even assault" (p. 4) whereas adaptation is "a simpler attempt to make texts 'relevant' or easily comprehensible to new audiences and readership via the process of approximation and updating" (p. 19).

Adaptation is also, "frequently a specific process involving the transition from one genre to another: novels 
into films, drama into musicals; the dramatization of prose narrative and prose fiction..." (Sanders, 2006, p. 9). Irobi's Sycorax does not possess any of these qualities of adaptation; it does not change the medium of The Tempest from play to prose or from text to cinema, etc. Rather, it is, when read in the larger intertextual context, seen as being "...linked to the postcolonial notion of hybridity" (Sanders, 2006, p. 17). Hybridism for Bhabha (1994), suggests how specific national cultures, ideas and events are "repeated, relocated and translated in the name of tradition" (p. 207) from its original culture into foreign or Diaspora nations. That is typical of Irobi's Sycorax which is a relocation of specific European popular literary culture into the Caribbean with unique injection of certain peculiarities of African indigenous oral performances. This relocation from one nation to another is new to African drama and accounts for the transnationalization of Irobi's Sycorax.

\section{The Transnational Turn in Irobi's Sycorax}

Irobi had written six plays before Sycorax. In those previous plays, especially in the last of the six entitled Cemetery Road (2009), Irobi demonstrates his fascination with his Igbo-African oral performances and the theatricality he has labelled the "akpankoro" performances. In all the other plays and in most of the poems that predate Sycorax, he concerned himself with life in postcolonial Nigeria, pay attention to the youth and the revivification of the mythologies of his immediate Ngwa people. Those plays distinguished him as a nationalist playwright. But with Sycorax, which Diala (2014) has designated “...Irobi’s most controversial play" (Blurb), the playwright shifts his approach and thematic concerns slightly away from his nationalist agenda and cultural affirmation to a more universal ethos.

Irobi in the play goes beyond national and continental geo-political boundaries to the West, to appropriate a continuing popular European literary tradition, alters, re-scripts and situates it in a contrasting clime. Such movement of the materials of literature from nation to nation for the purpose of commerce or pleasure; or the subversion of cannons and/or for the purpose of relocation of hegemonies typifies the transnational turn in Irobi's career. We shall recall that in the author's note, Irobi avers that Sycorax "marks a new approach to my playwriting and theater-making process" (p. 15). This new approach is one that provokes the aptitude to shade certain national appendages that limit Irobi's craft to Africa and precipitate instead, a more adroitness that accommodates the tendencies of a global character. He says "with Sycorax... I allow actors and Audiences in different parts of the world to participate, in a more democratic way, in the process of creating the performance text..." (Irobi, 2013, p. 5). Diala sees this move as corresponding with Brechtian-epic theatre (p. 206), but we see it as an appeal to bring global polarities into a singular syncretic arena.

The above inevitably informs in the play, the personalization of Caribbean (South America), Sycorax (Algeria-North Africa), Shakespeare (Europe), and the Asian Actor (in page 57) in an effort to bring different parts of the world to engage in that cross fertilization of ideas and values, that arise from the network of communications that globalization instigates. Simon During has defined globalization theory to be one which addresses the "geosynchronous communication technologies and massified transcontinental mobility to the formation of collectivities... bound together by neither history nor geography..." (During, 2000, p. 388). Thus, for us Sycorax becomes a synchronous communication of dramatis personae, at a particular moment, who have migrated from different locations. That communication in Sycorax destabilizes the metanarratives of European writers.

In Shakespeare's The Tempest for instance, Sycorax is spoken of as an unrepresented subaltern who cannot speak for him/herself. She is totally written out of history. It is through the words of the stereotypical character Prospero that Sycorax is named "...a witch, and one so strong/ That [she] could control the moon, make flows and ebbs,/And deal in her command without her power" (Act V, Scene 1). As for Caliban (now Caribbean in Irobi's Sycorax), Prospero says he is a "demi-devil/For he's a bastard one/... this thing of darkness..." (Act V, Scene1). In the synchronous play of Irobi, the muted Sycorax is given a voice to speak herself out. Her speech with the participating audience which represents the entire globe is a counter-narrative which subverts the rhetoric of power or the power in the rhetoric of Shakespeare and to an exponential degree, the writings of Homer and other Hellenic ethnographers.

In Irobi's Sycorax, Sycorax re-names herself. She is no longer the subservient or unrepresented subaltern. Thus, she laments, "my name is Sycorax... I salvage things from the jaws and the appetites of the ocean... I salvaged [Prospero] from the gullet of the Caribbean sea... who went on, after I had nursed him and his daughter to health on this very island, to malign and misrepresent me in the eyes of the world as a witch" (emphasis in the text 8-9). It is her misrepresentation that she wants to make right. With that passage, Irobi writes back to Shakespeare; and 'by 'writing back' to the West we were attempting to reshape the dialogue between the colonized and the colonizer" (Achebe, 2012, p. 55). He is stating unequivocally that the muted character has acquired the language of his/her exploiter and has gained a momentous impulse to speak.

Globalization has brought about in the words of During (2000), "the formation of collectives" (p. 388), those collectives are the platforms upon which things that ordinarily do not belong together are coalesced, debated and deconstructed into a more contemporaneous relevance. It is upon this backdrop that we regard 
Sycorax not as an adaptation but an(Other) text that merely references The Tempest. Sycorax does not follow the plot structure of The Tempest or its thematic concerns. It is more of an attempt to mobilize history's Other via a theatre that cuts across Brecht, the African village square and the Caribbean carnivalesque performances.

The Tempest has been studied as a play that privileges the earliest European colonial expansionist tendencies. Read in that regard, The Tempest presents Prospero (the rightful Duke of Milan), Alonso (the King of Naples), Gonzalo (an honest old Counsellor) and the Lords as colonialists whose boat fortunately, at two different intervals, arrive the island in the Mediterranean from Europe. The characters are presented as being mobile imperialists, like Charlie Marlow and, perhaps Mr. Kurtz in Joseph Conrad's Heart of Darkness moved from Europe to the Congo region of Africa; and Major Scobie in Graham Greene's The Heart of the Matter from Europe living in a colony in West Africa.

Ali Abdullah Mohammed Alzuhairi and Luo Yimin (2016) have argued that "The Tempest has, to a great extent, provoked many critics, historians and other writers to classify it as the most notable earlier works portraying the fundamental aspect of colonialism" ( $p$. 17). Those fundamental aspects include the dramatization of the movement of the imperialist from Europe to Africa and the hegemonic control of the natives represented by Caliban. Caliban himself has been re-imagined by critics and writers to be a corruption of the word 'cannibal' which was the word colonialists used to describe the colonized. The above notwithstanding, in Irobi's Sycorax, the relationship between the colonizer and the colonized is overhauled and destabilized. There is a similarity between Irobi's destabilization of that colonial narrative with what Zadie Smith has done with White Teeth (2000).

In both texts (Smith's White Teeth and Irobi's Sycorax), we observe, as Jay (2010) would say, that "the colonial machinery has gone into reverse. The mobility of the colonizer has become the mobility of the colonized, as they retrace the journeys of those who conquered their ancestors. With the descendants of those dislocated by colonial conquest having relocated to the very centre of colonial power, it is Englishness, not indigenousness that is at stake..." (p. 11). Irobi and his characters are allegories of those descendants whose forebears were dislocated and subdued by colonial powers and with the advent of globalization have moved to the global cultural epicentre or European metropolis. Thus, it is as Jay has rightly said, Euro-centrism that is being poisoned and vulgarized by that movement.

Hence, in Irobi's Sycorax, the characters are mobile. There is a progressive movement of natives from their cultures to the European literary hub which is represented as Stratford Upon Avon. The Director of the play within the play named Adrien Nobleman doubles as the playwright Esiaba Irobi himself. It is through him that we first encounter that vulgarization of Englishness. He is asked to stage The Tempest at Stratford Upon Avon, and instead of sticking to the homogeneity that distinguish the English or Elizabethan theatre, he prefers to people the stage with a multicultural and hybrid cast thereby rendering the English habit banal.

The director of the play within the play confesses that "towards the end of my three year tenure at the RSC, I was asked to direct Shakespeare's masterpiece The Tempest. I decided to do it with a multicultural cast because I thought it was only sensible, at the beginning of the twenty-first century..." (p. 29). His wife Elizabeth warns him of the implications of such a global approach to a homogenous cultural event saying "of all Shakespeare's plays, The Tempest is my favourite. That's why I don't want to see it vulgarized by your so-called actors of color" (pp. 31-32). That becomes the first attack of transnationalism on a beleaguered national literature. So, he gets what he calls his "new transnational and multicultural" (p. 34) cast as against what was routine. And the consequences are disastrous.

The second assault comes from Caribbean who is also called Caliban or Emperor Haile Salassie. His names reflect his hybrid origin. Haile Salassie is his African origin and Caribbean or Cari Boy reflects his South American origin. This hydridity equally reflects in his language which is a creolized version of an English language. Remarkably, Caribbean is a member of the cast to act in the play-within-the-play, and his role is to act Caliban. His conversation with the Director (Nobleman) is insightful: the Director asks him what he is doing during a particular rehearsal and he replies, "remembering mi lines as yuh can si! Am bringing Jah into di jam tonight" (p. 37), introducing a powerful impenetrable Jamaican accent. He continues, "Director, mi study mi lines very careful last night. Did some extensive research on Di Tempest and Jah most high revealed to mi dat dis play is set in di Caribbean" (p. 37). This passage is atrocious. It overturns the grammar of Her Majesty, the Imperial Queen of England by introducing other varieties or creolized versions that have gained mobility and relocated to the seat of language imperialism to attack and pulverize it. This is a counter-attack on the English language that rubbed Caribbean his indigenous language.

The third attack follows the awakening of Shakespeare. As the play progresses, the cast which is multicultural moves to the site of globalization, awaken Shakespeare and interrogates him about his creations in The Tempest. The hallmark of that exercise is when "the cast grab Shakespeare, strip him naked, splay him against the wall and whip him publicly on the buttocks. Twelve strokes" (p. 79). This event validates our argument. If Sycorax were to be an adaptation, Shakespeare would have been eulogized by the cast instead of being assaulted. The assault is a metaphor and the summation of all Irobi sets out to do with Sycorax - to attack 
Shakespeare, not to imitate him. As Caliban proposes, "Shakespeare's plays are not museum pieces. We cut and paste. We improvise. We change the narrative. We give The Tempest a new structure. A new imagination. A new life. We give it colour. We are people of colour" (p. 60). The scene is symbolically set to delegitimize the European canon.

At this point, we shall once more recall Irobi's contention in the author's note that Sycorax “...marks a new approach..." to his dramaturgy; "my new approach to play-making parallels the way theatre is traditionally created in indigenous African communities... In the wake of globalization, I believe that African diasporic theatre must not only resist but also offer Western mainstream, commercial, theatre, a more inclusive option" (pp. 5/6-7). Very importantly, Irobi's new approach already suggests the movement of theatre cultures back and forth Africa and the West, such that both rob each other its idiosyncratic and isolated ingredients. Appiah (1991) has argued that "if there is a lesson in the broad shape of this circulation of cultures, it is surely that we are all already contaminated by each other, that there is no longer a fully autochthonous echt-African culture awaiting salvage by our artists (just as there is of course no American culture without African roots)" (Appiah, 1991, p. 354). One of the commodities which Africa has contributed and shared in Irobi's multi-cultural play is the material of African ritual chants which he excavated from his Igbo ritual productions.

In Act One, Scene Three, at "the graveyard of Holy Trinity church, Stratford-Upon-Avon" (p. 65), the playwright involves the services of an Obeah woman to conjure-up the spirit of Shakespeare. That ritual site reinvokes, a typical ritual scene that is typical of the Igbo traditional practice during which the spirit of a dead relative or enemy is culled forth from his/her tomb to be interrogated (especially during disputes). The ritual is purely religious and sacred and at the same time may serve as the origin of drama/theatre in Igbo (debates about this abound).

Obeah ritual has been studied by scholars from different dimensions. One of the prevailing conclusions is its link to Africa. Chambers (1997) studies the lexical correlations of Obeah practices and associates it with the practices "... of the ndi obea (or dibia) of precolonial Igboland" (p. 18). He sees Obeah as a creolized version of 'Ndi Obia' which literally translates as a group of new comers into the slave regions in the Caribbean who are "known across Igboland and the heavily Ibolesque coastal settlement as powerful and dangerous, and thus feared and respected everywhere, such [as] 'doctors"” (Chanbers, 1997, p. 18). Also Johnston (1910) argues that the word 'Obia', truly "...seems to be a variant or a corruption of an Efik or Ibo word from north east or east of the Niger delta, which means "Doctor"' (p. 17). To take us further, Handler and Bilby (2001) assert that "it is not unlikely that the term 'Obeah' were derived from Igbo or a related language" (p. 92). It is in the word of Umeh (1997) that we hear the Obeah or 'Dibia' is "holistic" in his/her practices which involves even voodooism and necromancy (p. 19).

In Sycorax the Obeah scene adds an African theme that brings to mind, the ancestral link Caribbean and Sycorax share with the dramatist Irobi. Thus what he calls "a powerful Caribbean ritual chant" (p. 65) is in actuality a trans-located tradition, dislodged from its origin by one of the earliest forms of globalization - the slave trade. The ritual chant; its suggested symbols, and its enactment install an undeniable African aura in the play, just as Caribbean's band together with their enthusiasm or verve inaugurate the kinetics of South American materials into the play.

\section{Conclusion}

It is our contention from the foregoing that describing Sycorax as an adaptation is a misreading of it; the stamp of adaptation inferiorises the play, making it something of a secondary text and an imitation of an original. It is our view that the imitational perception is not helpful for analyzing such a work with a novel ingenuity as Sycorax. To say that it is an adaptation is to say that it is, as Naremore (2000) may suggest, a "belated, middlebrow, or culturally inferior" (p. 6) play. It will fall into one or all of these terms used by McFarlane (1996) "tampering", "interference", "violation" (p. 12) of the original play. It will correspond with such terms used by Stam (2000) as "betrayal", "deformation", "perversion", "infidelity" or "desecration" (p. 54) of a primary work whose presence will perpetually haunt the Sycorax. Sycorax will therefore become a text in a "second degree" (Genette, 1982, p. 3). It is rather our view in this essay that Sycorax is more of an appropriation of materials and facts from The Tempest and its author than an adaptation of the play, and that it is through this technique of appropriation that Irobi pulls down national barriers in his creative imagination thereby laying the foundation of what he describes as "... a new approach to my playwriting and theater-making process" (p. 5).

Sycorax is a thus play that realizes itself within the liminal margin between Africa, America and Europe. It demonstrates the unbounded and unrestrained exchange of cultures by the agency of globalization and foregrounds what the future holds for the exchange in African literature. It has done what Irobi wanted: bringing the particular emotions of the celebrated Other to global perspective. It has set the stage for the emergence of an art that will re-present the colonized as one who is not celebratory about his Otherness but inquisitive for answers and eager to challenge stereotypes. 


\section{Reference}

Achebe, C. (2012). There was a country: A personal history of Biafra. New York, NY: Penguin Group.

Alzuhairi, A., Mohammed, A., \& Yimin, L. (2016). Canonical colonial approaches in Shakespeare's the tempest. International journal of English and literature, 7, 16-20.

Appiah, K. A. (1991). Is the post- in postmodernism the post- in postcolonial? Critical thinking, 17, 2, 336-357.

Barthes, R. (1977). From work to text. Trans. Stephen Heath. In Roland Barthes image-music-text. New York, NY: Hill and Wang. 155-164.

Bhabha, H. (1994). The location of culture. New York, NY: Routledge.

Chambers, D. (1997). My own nation: Igbo exiles in the Diaspora. Slavery and abolition. New York, NY: Routledge.

Clark-Bekederemo, J. P. (1970). The example of Shakespeare. London: Longman.

Diala, I. (2014). Esiaba Irobi's drama and the postcolony: Theory and practice of postcolonial performance. Ibadan: Kraft Books Limited.

During, S. (2000). Postcolonialism and globalization: Towards a historicization of their inter-relations. Cultural studies, 14, 3-4, 385-404.

Genette, G. (1982). Palimpsestes: La litterature au second degre. Paris: Seuil.

Giddens, A. (1991). The consequences of modernity. Cambridge, UK: Polity Press.

Hamilton, B. D. (1990). Virgil and the tempest: The politics of imitation. Ohio: Ohio State University Press.

Handler, J. S. and Bilby, K. M. (2001). Notes and documents - On the early use and origin of the term 'Obeah' in Barbados and the Anglophone Caribbean. Slavery \& abolition: A journal of slave and post-slave studies, $22,2,87-100$

Hinds, S. (1998). Allusion and intertext: Dynamics of appropriation in Roman poetry. Cambridge: Cambridge University Press.

Hutcheon, L. (2006). A theory of adaptation. New York, NY: Routledge.

Irobi, E. (2013). Sycorax. Enugu: ABIC Books \& Equips Ltd.

Jay, P. (2010). Global matters: The transnational turn in literary studies. New York, NY: Cornell University Press.

Johnston, H. (1910). The negro in the new world. New York, NY: MacMillian Company.

McFarlane, B. (1996). Novel to film: An introduction to the theory of adaptation. Oxford: Clarendon Press.

Naremore, J. (Ed.). (2000). Introduction: Film and the reign of adaptation. Film adaptation. New Brunswick, NJ: Rutgers University Press, pp. 1-16.

Sanders, J. (2006). Adaptation and appropriation. New York, NY: Routledge.

Stam, R. (2000). The dialogies of adaptation. In J. Naremore (Ed.), Film adaptation. New Brunswick, NJ: Rutgers University Press, pp. 54-76.

Sturm, J. A. (1547) Ritch storehouse or treasure for nobility and gentlemen (T. B. Gent, Trans.). London: Routledge.

Umeh, J. A. (1997). After God is dibia: Igbo cosmology, divination and sacred science in Nigeria. London: Karnak House.

Young, O. J. (2008). Cultural appropriation and the arts. Victoria: Blackwell Publishing. 